\title{
Maltose transport in Aeromonas hydrophila: purification, biochemical characterization and partial protein sequence analysis of a periplasmic maltose-binding protein
}

\author{
Kerstin Höner zu Bentrup, Roland Schmid and Erwin Schneider
}

Author for correspondence: Erwin Schneider. Tel: +49 541969 2855. Fax: +49 5419692870.

Universităt Osnabrück, Fachbereich

Biologie/Chemie, Abteilung

Mikrobiologie, D-49069

Osnabrück, FRG
A clinical isolate of Aeromonas hydrophila was demonstrated to transport $\left[{ }^{14} \mathrm{C}\right]$ maltose with similar kinetics to enteric bacteria $\left(K_{m}: 0.3 \mu \mathrm{M} ; V_{\max }: 22 \mathrm{nmol}\right.$ min $^{-1}$ per $10^{9}$ cells). The uptake of $\left[{ }^{14} \mathrm{C}\right]$ maltose was completely inhibited in the presence of unlabelled maltose or maltodextrins, whereas other mono- and disaccharides, such as glucose, galactose, sucrose, lactose or melibiose, had no effect. A protein with an apparent molecular mass of $39 \mathrm{kDa}$ (maltose-binding protein; MBP) was identified in osmotic-shock fluid of maltose-grown cells by SDS-gel electrophoresis, and was purified to homogeneity by either amylose affinity chromatography or ion-exchange chromatography. Equilibrium dialysis experiments revealed the ability of the purified protein to bind $\left[{ }^{14} \mathrm{C}\right]$ maltose with high affinity $\left(K_{\mathrm{D}}=1.6 \mu \mathrm{M}\right)$. Unlabelled maltose and maltodextrins competed for the binding site. In a reconstitution experiment, A. hydrophila MBP poorly restored the transport activity of a binding-proteindeficient Escherichia coli ( $\Delta$ malE) mutant. N-terminal sequence analyses of the purified native protein and of peptides generated by cleavage with $\mathrm{CNBr}$ and subsequently separated by HPLC revealed about $56 \%$ identical amino acid residues, as compared to enterobacterial MBPs. We conclude that maltose is transported into A. hydrophila via a binding-protein-dependent transport system.

Keywords: Aeromonas hydrophila, maltose-binding protein, maltose transport, reconstitution, partial protein sequence

\section{INTRODUCTION}

Maltose and maltodextrins can be utilized by a wide variety of bacteria as sole sources of carbon and energy. These include genera that are grouped in the 'purple photosynthetic bacteria' on the basis of 16S rRNA sequence comparisons, such as Paracoccus, Xanthomonas, Neisseria, the enteric group, Vibrio and Aeromonas, and also Gram-positive bacteria, such as Bacillus, Staphylococcus and Streptococcus (Woese, 1987).

However, only in the case of Escherichia coli and other Enterobacteriaceae has extensive knowledge concerning the uptake and degradation of these sugars been accumulated (reviewed by Schwartz, 1987, and by Schneider, 1990). These bacteria are equipped with an inducible bindingprotein-dependent (or periplasmic-) type of transport

Abbreviation: MBP, maltose-binding protein. system that mediates the translocation of the nutrient across the cytoplasmic membrane at the expense of ATP. Maltose (at micromolar concentrations) and maltodextrins pass through the outer membrane by facilitated diffusion through a specific channel (maltoporin or LamB). In the periplasm, the nutrient is bound with high specificity and high affinity $\left(K_{\mathrm{D}}\right.$ approx. $\left.1-2 \mu \mathrm{M}\right)$ to a soluble binding protein, MalE or maltose-binding protein (MBP), and subsequently delivered to a hetero-oligomeric protein complex localized to the cytoplasmic membrane which, by a still unknown mechanism, translocates the solute into the cytoplasm. The transport complex is composed of one copy each of the hydrophobic integral membrane proteins MalF and MalG, and of two copies of the peripherally associated hydrophilic subunit MalK (Davidson \& Nikaido, 1991), which has been demonstrated to bind and hydrolyse ATP (Walter $e$ t al., 1992). Reconstitution experiments with the purified $\mathrm{MalFGK}_{2}$ complex suggested that, upon interaction of the substrate- 
loaded binding protein with domains of MalF and MalG exposed to the periplasm, MalK displays an ATPase activity, thereby coupling the transport process to the hydrolysis of ATP (Davidson et al., 1992).

Binding-protein-dependent transport systems have been described for a variety of substrates, including sugars, amino acids, oligopeptides, ions and vitamins (Ames, 1986), and have been discovered in both Gram-negative and Gram-positive eubacteria. Due to the lack of a periplasmic space, in the latter organisms the binding protein probably remains associated with the surface of the cell membrane by its lipoprotein-like $\mathrm{N}$-terminus (Gilson et al., 1988).

With respect to the general structural organization of the membrane-bound protein complex (two hydrophobic domains and two ATP-binding domains), and due to the presence of two short sequence motifs in the primary structure of the ATP-binding components, which have been proposed to constitute a binding domain for nucleotides (Walker et al., 1982), these systems belong to a growing superfamily of transporters (ATP-BindingCassette transporters or traffic ATPases). Operating from bacteria to man, $A B C$ transporters are involved in the uptake or export of a large variety of substrates (reviewed by Ames et al., 1990; Higgins, 1992).

In contrast to the Enterobacteriaceae, very little is known about the mechanism of transport by which other eubacteria accomplish the uptake of maltose and maltooligosaccharides. Thus far, only data on Gram-positive organisms are available. Based on experiments with whole cells and cell extracts, Tagney et al. (1992a, b) recently concluded that Bacillus subtilis and Bacillus licheniformis transport maltose by a proton symport mechanism. The sequences of two hydrophobic membrane proteins from Clostridium thermosulfurogenes display significant similarity to MalF and MalG of E. coli, implying that this organism might possess a binding-protein-dependent type of transporter for maltose/maltodextrins (Bahl et al., 1991). In Streptococcus pneumoniae, the products of the genes malX, malC and malD, which also show sequence homology with the E. coli proteins MalE, MalF and MalG, respectively, appear to be components of a maltodextrinspecific transporter that is, however, dispensable for the uptake of maltose (Puyet \& Espinosa, 1993). Similarly, a binding-protein-dependent transport system from Streptococcus mutans is required for growth on melibiose, raffinose and isomaltotriose, but insertional inactivation of the genes had no effect on growth on maltose (Russell et al., 1992).

Thus, in order to identify binding-protein-dependent transport systems that are specific for maltose and maltodextrins in non-enteric Gram-negative bacteria, we have screened for the presence or absence of maltoseinducible periplasmic proteins by SDS-PAGE.

In the present communication we report on the identification and characterization of a maltose-specific periplasmic binding protein in Aeromonas bydropbila $\left(\mathrm{MBP}_{A . h .}\right)$. Species of the genus Aeromonas are facult- atively anaerobic Gram-negative rods which belong to the same phylogenetic subgroup but are clearly differentiated from the 'enterics' (Woese, 1987). In particular, $A$. bydropbila, which is pathogenic to humans, is of interest because it secretes a wide range of extracellular proteins (Janda, 1985), including an $\alpha$-amylase (Gobius \& Pemberton, 1988) and possible virulence factors (Chakraborty et al., 1984, 1987; Leung \& Stevenson, 1988).

\section{METHODS}

Organisms and growth conditions. A. bydropbila (clinical isolate provided by R. Holländer, St Jürgens Krankenhaus, Bremen, FRG) was grown at $30^{\circ} \mathrm{C}$ in either rich medium (LB; Miller, 1972) or in minimal medium (VB; Roth, 1970), supplemented with maltose $(0 \cdot 4 \%, \mathrm{w} / \mathrm{v})$. E. coli strain HS3018 (malT ${ }^{-1}$ AmalE444; Shuman, 1982), kindly provided by W. Boos, Universität Konstanz, FRG, was grown at $37^{\circ} \mathrm{C}$ in minimal medium (VBC; Roth, 1970), supplemented with glycerol $(0.4 \%, \mathrm{v} / \mathrm{v})$ as the sole carbon source.

Preparation of osmotic-shock fluid. Proteins were released from the periplasm of maltose-grown cells of $A$. bydropbila by the method of Nossal \& Heppel (1966).

Purification of $\mathrm{MBP}_{\text {A.h. }}$ by affinity chromatography. Osmoticshock fluid $(8 \mathrm{ml})$ was dialysed extensively against $10 \mathrm{mM}$ Tris $/ \mathrm{HCl}, \mathrm{pH} 7 \cdot 5$, and loaded on a crosslinked amylose column $(2.6 \times 10 \mathrm{~cm})$ (Ferenci \& Klotz, 1978) equilibrated with buffer at $4{ }^{\circ} \mathrm{C}$. Subsequently, the matrix was extensively washed with buffer to remove contaminating proteins, and eventually the MBP was eluted by washing the column with buffer containing $10 \mathrm{mM}$ maltose. Fractions containing binding protein were collected, concentrated by ultrafiltration and dialysed against buffer lacking maltose.

Purification of $\mathrm{MBP}_{\mathrm{A} . h \text {. }}$ by ion-exchange chromatography. Dialysed shock fluid $(6 \mathrm{ml})$ was applied onto a DEAE-Sephacel column $(2.6 \times 14 \mathrm{~cm})$ (Pharmacia) and washed consecutively with $10 \mathrm{mM}$ Tris/ $\mathrm{HCl}, \mathrm{pH} \mathrm{7.5}$, and the same buffer supplemented with $0.25 \mathrm{M} \mathrm{NaCl}$. $\mathrm{MBP}_{A . h}$. was eluted by washing the column with buffer containing $1 \mathrm{M} \mathrm{NaCl}$. The relevant fractions were collected, concentrated by ultrafiltration and dialysed against buffer.

SDSPAGE. Electrophoresis was routinely performed according to Laemmli (1970), using $10 \%(\mathrm{w} / \mathrm{v})$ acrylamide. For the separation of peptide fragments generated by $\mathrm{CNBr}$, the tricine system of Schägger \& von Jagow (1987) was applied. The gels were prepared with $10 \%$ acrylamide and $6 \mathrm{M}$ urea.

Maltose-binding activity of purified $\mathbf{M B P}_{\text {A.h. }}$. The binding of radiolabelled maltose to the MBP was determined by equilibrium dialysis. Purified MBP $(160 \mu \mathrm{g}$ in $0.1 \mathrm{ml})$ was dialysed for $24 \mathrm{~h}$ at $4{ }^{\circ} \mathrm{C}$ against $10 \mathrm{mM}$ Tris $/ \mathrm{HCl}, \mathrm{pH} \mathrm{7.5}$, containing increasing concentrations of $\left[{ }^{14} \mathrm{C}\right]$ maltose $[0.34 \mathrm{mM}, 200 \mu \mathrm{Ci}$ $\mathrm{ml}^{-1}\left(7 \cdot 4 \mathrm{MBq} \mathrm{ml}^{-1}\right)$; Amersham] $(0 \cdot 1-5 \mu \mathrm{M} ; 2 \mathrm{ml}$ total volume). Subsequently, the complete protein solution from the dialysis bag, as well as an aliquot $(0.1 \mathrm{ml})$ from the buffer, were assayed for radioactivity by scintillation counting.

Transport assay. Transport of maltose was measured by uptake of $\left[{ }^{14} \mathrm{C}\right]$ maltose. Cells of $A$. bydropbila were grown to late exponential phase in VB salts supplemented with maltose $(0.4 \%$, $\mathrm{w} / \mathrm{v}$ ) as the sole carbon source, harvested, and washed twice in VB salts. Eventually, the cells were resuspended in VB salts containing chloramphenicol $\left(0 \cdot 1 \mathrm{mg} \mathrm{ml}^{-1}\right)$ to an $\mathrm{OD}_{650}$ of 12 . Each transport assay $(1 \mathrm{ml})$ contained $10 \mu \mathrm{l}$ washed cells, $989 \mu \mathrm{l}$ $\mathrm{VB}$ salts and $1 \mu \mathrm{l}\left[{ }^{14} \mathrm{C}\right] \mathrm{maltose}$. At the indicated time intervals, 
aliquots $(180 \mu \mathrm{l})$ were filtered (on Schleicher \& Schuell OE67 $0.45 \mu \mathrm{m}$ membranes) and washed with $5 \mathrm{ml} \mathrm{VB}$ salts. The filters were dried at $80^{\circ} \mathrm{C}$ and counted in Hydroluma (Baker). Routinely, each assay was run in duplicate.

Reconstitution of maltose transport in $\boldsymbol{E}$. coli. These experiments were essentially performed as described by Brass (1986). Strain HS3018 was grown in VBC salts containing glycerol $(0.4 \%, v / v)$ to an $\mathrm{OD}_{650}$ of between 0.3 and 0.6 . A total of $10^{9}$ cells were collected by centrifugation and washed at room temperature with $0 \cdot 1 \mathrm{M}$ Tris $/ \mathrm{HCl}, \mathrm{pH} 7 \cdot 5$, and $0 \cdot 1 \mathrm{M}$ potassium phosphate buffer, $\mathrm{pH} 7.5$ (1 ml each), respectively. Subsequently, cells were resuspended in $50 \mu \mathrm{l} 0.1 \mathrm{M}$ Tris $/ \mathrm{HCl}$, $\mathrm{pH} 7 \cdot 5$, containing $0.3 \mathrm{M} \mathrm{CaCl}_{2}$ and purified $\mathrm{MBP}\left(15 \mathrm{mg} \mathrm{ml}^{-1}\right.$ final concentration). The mixture was shaken at $4{ }^{\circ} \mathrm{C}$ for $30 \mathrm{~min}$ and washed with $1 \mathrm{ml} 0.9 \% \mathrm{NaCl}$. Finally, the cell pellet was resuspended in $1 \mathrm{ml} \mathrm{VBC}$ salts and kept at room temperature until used.

Cleavage of MBP with CNBr. Purified MBP $(0.5 \mathrm{mg})$ was incubated overnight at room temperature with $20 \mathrm{mM} \mathrm{CNBr}$ in $80 \%(\mathrm{v} / \mathrm{v})$ formic acid $(0.3 \mathrm{ml}$ final volume $)$ and subsequently evaporated in a SpeedVac (Savant). The pellet was washed twice with double-distilled water and dried again in a SpeedVac overnight. Finally, the pellet was dissolved in $80 \mu \mathrm{l} 50 \mathrm{mM}$ Tris $/ \mathrm{HCl}, \mathrm{pH} 8$, and stored at $-20^{\circ} \mathrm{C}$.

$\mathrm{N}$-terminal amino acid sequence analysis. $\mathrm{CNBr}$ cleavage fragments were separated on a reverse-phase HPLC column $\left(C_{4}\right.$, Vydac), applying an acetonitrile gradient (0-70\%) in $0.1 \%$ trifluoroacetic acid. Peptide-containing fractions were collected manually into Eppendorf tubes based on a UV absorption at $210 \mathrm{~nm}$ and immediately dried in a SpeedVac overnight. Samples were stored at $-20^{\circ} \mathrm{C}$. For sequence analysis, peptides from five well-separated fractions or purified mature MBP were dissolved in $50 \%(\mathrm{v} / \mathrm{v})$ acetonitrile and spotted on a glass filterdisc, pretreated with polybrene. The cycle used for sequencing was a slight modification of the NORM cycle designed for the model $473 \mathrm{~A}$ of Applied Biosystems.

Protein determination. Protein concentrations were determined by the method of Dulley \& Grieve (1975).

\section{RESULTS}

\section{Maltose transport by washed cells of $A$. hydrophila}

We measured the initial rate of maltose transport for a maltose-grown culture of $A$. bydropbila. After the addition of a low concentration of $\left[{ }^{14} \mathrm{C}\right]$ maltose $(0.34 \mu \mathrm{M})$, transport was linear for 2 min and occurred at an average rate of $6.5 \mathrm{nmol} \mathrm{min}{ }^{-1}$ per $10^{9}$ cells (Fig. 1). No uptake of radiolabelled substrate was observed with cells grown in the presence of glucose as the sole source of carbon and energy (not shown). The rate of maltose transport was completely inhibited when maltose-grown cells were preincubated with an excess of unlabelled maltose or maltodextrins (1 mM each) (Fig. 1). In contrast, the transport rate was not significantly altered in the presence of glucose (Fig. 1) or other mono- and disaccharides, such as galactose, lactose, melibiose or sucrose (not shown).

The kinetics of transport were determined by measuring the initial rates of $\left[{ }^{14} \mathrm{C}\right]$ maltose uptake at various substrate concentrations for maltose-grown cells. Non-linear analysis of the data from three independently performed experiments revealed an apparent $K_{\mathrm{m}}$ of $0.3 \mu \mathrm{M}$ and a
$V_{\max }$ of $22 \mathrm{nmol} \min ^{-1}$ per $10^{9}$ cells (data not shown). These values are in good agreement with data reported for enterobacterial binding-protein-dependent transport systems for both maltose (Dahl \& Manson, 1985) and other substrates (Ames, 1986).

\section{Purification and properties of a maltose-inducible periplasmic protein $\left(\mathrm{MBP}_{\mathrm{A} . h .}\right)$}

$A$. bydropbila was grown in rich medium in the presence or absence of maltose $(0 \cdot 2 \%, \mathrm{w} / \mathrm{v})$ and subjected to an osmotic shock to release periplasmic proteins. After centrifugation, SDS-PAGE revealed a protein band with an apparent molecular mass of $39 \mathrm{kDa}$ that was found in the concentrated supernatant of maltose-grown cells but was absent in the shock fluid of uninduced cells (Fig. 2, lanes 2 and 3). Since preliminary binding assays had indicated that the concentrated osmotic-shock fluid from induced cells exhibited a maltose-binding activity (not shown), we applied two different procedures to isolate the protein (also see 'Methods'). Both methods have been developed for the purification of the MBP from E. coli (Ferenci \& Klotz, 1978; Dean et al., 1992). According to the protocol described by Dean et al. (1992), the concentrated and dialysed shock fluid was subjected to ionexchange chromatography, and bound proteins were eluted by increasing salt concentrations. Under these conditions, $\mathrm{MBP}_{A, h}$. eluted at $1 \mathrm{M} \mathrm{NaCl}$ (not shown). Alternatively, the $39 \mathrm{kDa}$ protein was purified from the shock fluid by affinity chromatography using cross-linked amylose (Ferenci \& Klotz, 1978). Only those proteins which contain binding sites for maltose or maltodextrins are retained by the matrix, whereas contaminating proteins are found in the flow-through. Elution of bound proteins is conveniently achieved by the addition of maltose to the running buffer. As shown in Fig. 2, lanes 4

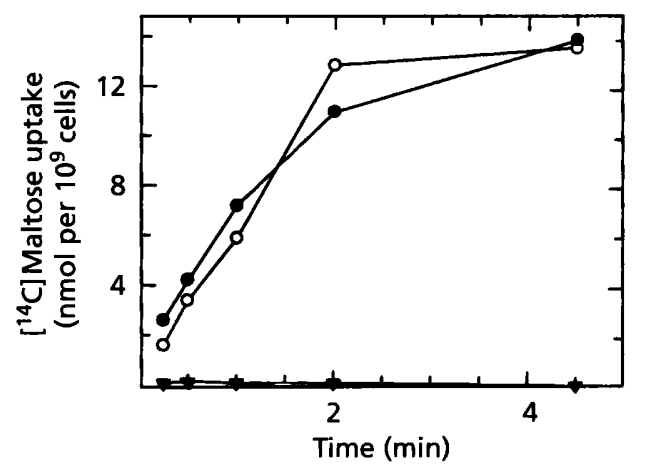

Fig. 1. Initial rate of $\left[{ }^{14} \mathrm{C}\right]$ maltose transport. Cells of $A$. hydrophila were grown and washed as described in Methods. Each transport assay contained $10 \mu \mathrm{l}$ cells in VB salts $(1 \mathrm{ml})$. The reaction was initiated by the addition of $\left[{ }^{14} \mathrm{C}\right]$ maltose (final concentration $0.34 \mu \mathrm{M})$. Aliquots were withdrawn at the indicated time intervals and treated as described in Methods. The substrate specificity was determined by measuring the uptake of $\left[{ }^{14} \mathrm{C}\right]$ maltose in the presence of unlabelled sugars (1 $\mathrm{mM}$ ). Symbols: $O$, no addition; - glucose; $\nabla$, maltose or maltodextrins (Pfanstiehl). The data presented are means of duplicate experiments. 


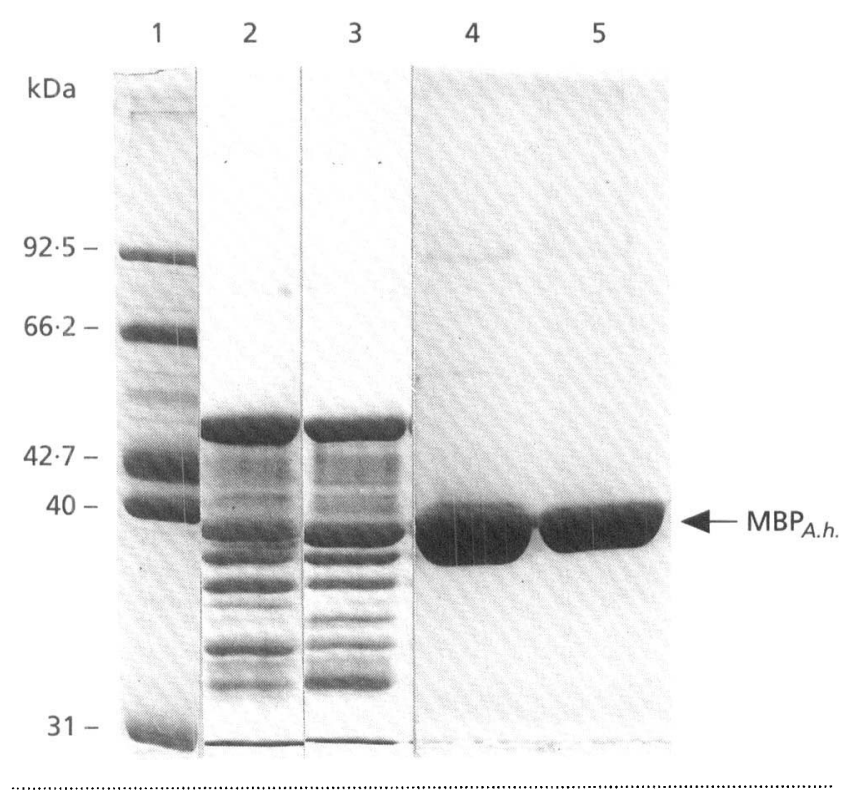

Fig. 2. Summary of purification of $M B P_{A . h}$. Equal amounts of protein $(18 \mu \mathrm{g})$ were subjected to SDS-PAGE. Proteins were visualized by Coomassie-blue staining. Lanes: 1 , molecular mass markers (Boehringer Mannheim), including the purified MBP from $S$. typhimurium ( $40 \mathrm{kDa}) ; 2$, concentrated osmotic-shock fluid from cells of $A$. hydrophila grown in LB; 3 , concentrated osmotic-shock fluid from cells grown in LB supplemented with $0.2 \%(w / v)$ maltose; $4, \mathrm{MBP}_{A . h}$ purified by ion-exchange chromatography; 5, MBP ${ }_{A . h}$. purified by amylose affinity chromatography. The position of $\mathrm{MBP}_{\text {A.h. }}$ is marked by an arrow.

and 5 , both procedures yielded highly purified preparations of $\mathrm{MBP}_{A . h \text {. }}$

Western immunoblot analysis revealed only a very weak cross-reactivity of purified $\mathrm{MBP}_{A . h}$. with an antiserum raised against the MBP of Salmonella typhimurium $\left(\mathrm{MBP}_{\text {S.t. }}\right)$ (dilution $5 \times 10^{-3}$ ), while MBP from several enterobacteria exhibited strong cross-reactivities with the same antiserum, even at a 10 -fold higher dilution (data not shown; see Brzostek et al., 1993).

The ability of the purified protein to bind maltose was measured using equilibrium dialysis. Analysis of the data from three experiments revealed that $\mathrm{MBP}_{A, h}$. bound $\left[{ }^{14} \mathrm{C}\right]$ maltose with high affinity $\left(K_{\mathrm{D}}=1.6 \mu \mathrm{M}\right)$. This value is in excellent agreement with dissociation constants reported for enterobacterial MBPs (Dahl \& Manson, 1985). Binding of $\left[{ }^{14} \mathrm{C}\right]$ maltose was fully blocked in the presence of $0.1 \mathrm{mM}$ unlabelled maltose or maltodextrins, but only reduced to a minor extent by $0.1 \mathrm{mM}$ galactose, lactose and sucrose (to $66 \%, 72 \%$ and $83 \%$, respectively, of the control). Glucose or glycerol did not interfere with binding of radiolabelled maltose.

\section{Reconstitution of maltose transport in $E$. coli ( $\Delta$ malE)}

The defect in maltose transport of an E. coli ( $\triangle \mathrm{malE}$ malT ${ }^{c}$ ) strain lacking the MBP can be overcome by introducing purified binding protein into the periplasm of calcium-permeabilized cells (Brass, 1986). This method

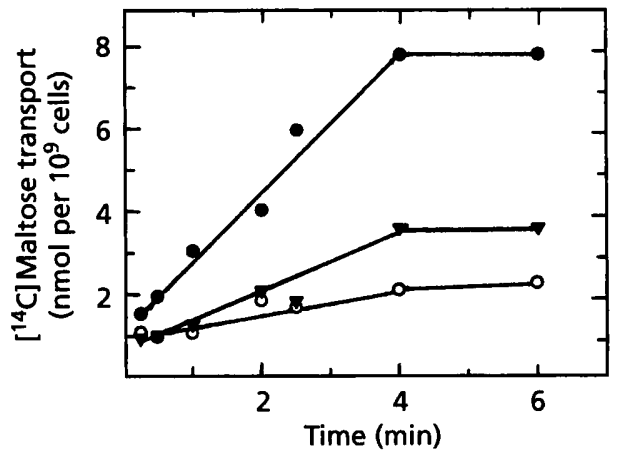

Fig. 3. Reconstitution of maltose transport. Cells of $E$. coli strain HS3018 ( $\triangle$ malE344) were grown to mid exponential phase in VBC salts containing glycerol, harvested and the outer membrane was permeabilized as described in Methods. Pretreated cells were incubated in the absence $(O)$ or presence of $\mathrm{MBP}_{\text {A.h. }}(\nabla)$ or $\mathrm{MBP}_{\text {s.t. }}(0)$, respectively, for $30 \mathrm{~min}$ at $4{ }^{\circ} \mathrm{C}$, washed with $0.9 \% \mathrm{NaCl}$, resuspended in VBC salts $(1 \mathrm{ml})$ and assayed for transport as described in the legend to Fig. 1. The mean values of three experiments are presented.

provides a convenient way to test whether foreign MBPs function in E. coli. We performed such a reconstitution experiment with $\mathrm{MBP}_{A . h .}$, using the $\mathrm{MBP}_{\text {S.t. }}$ as a control. The latter has been shown previously to restore transport as efficiently as E. coli MBP (MBP ${ }_{\text {..c. }}$ ) (Dahl \& Manson, 1985). As shown in Fig. 3, transport of $\left[{ }^{14} \mathrm{C}\right]$ maltose into strain HS3018 was restored by $\mathrm{MBP}_{\text {S.t. }}$, with an initial rate of uptake that is highly compatible with data reported by Brass (1986). In contrast, in the presence of $\mathrm{MBP}_{A . h}$. maltose uptake was observed only at a much reduced rate. These results indicate that maltose-loaded $\mathrm{MBP}_{A . h}$. is only poorly recognized by the membrane-integral components MalF and MalG of E. coli in order to initiate the subsequent translocation steps (also see below).

\section{Sequence analysis of native MBP and CNBr-generated fragments}

We determined the $\mathrm{N}$-terminal amino acid sequence of $\mathrm{MBP}_{A . h .}$. by using a gas-phase sequenator. Seventeen out of eighteen amino acids were clearly identified and could be aligned with the available $\mathrm{N}$-terminal sequences of MBP from E. coli, Enterobacter aerogenes and S. typhimurium (Dahl et al., 1989) (Fig. 4). While the enterobacterial proteins are completely identical at the $\mathrm{N}$-terminus (up to E28), the sequence from $A$. bydropbila revealed at least four amino acid replacements. Strikingly, however, these substitutions are located within the first ten amino acids, whereas the sequence from Ile11 to (at least) Asn 18 is fully conserved. This peptide segment includes Asp14 and Lys15, the sidechains of which are involved in hydrogenbonding interactions of the $E$. coli binding protein and maltose, as revealed from the crystal structure (Spurlino $e t$ al., 1991).

In order to obtain additional information on the primary structure of $\mathrm{MBP}_{A . h}$, peptide fragments were generated by exposing the purified protein to $\mathrm{CNBr}$, dissolved in $80 \%(\mathrm{v} / \mathrm{v})$ formic acid. As shown in Fig. 5, the cleavage 

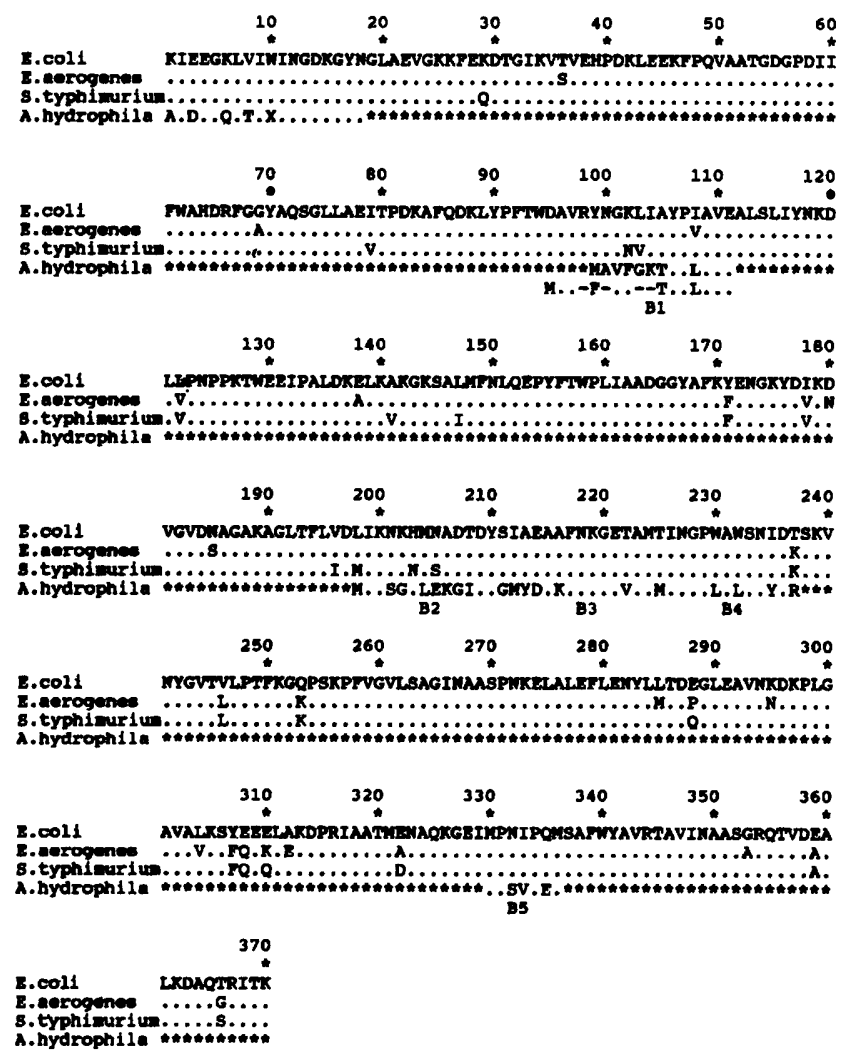

Fig. 4. Alignment of $\mathrm{N}$-terminal amino acid sequences of native $\mathrm{MBP}_{\text {A.h }}$ and peptide fragments generated by $\mathrm{CNBr}$ with enterobacterial MBP sequences. Sequence data of $A$. hydrophila were obtained as described in Methods. The enterobacterial sequences were taken from Dahl et al. (1989). The differences between the sequences are displayed. Identical amino acids are indicated by dots. The peptide fragments B1 to B5 start with the respective methionine residue at which $\mathrm{CNBr}$ cleavage had occurred (B1, residue 99-111; B2, residue 188-211; B3, residue 212-224; B4, residue 225-237; B5, residue 330-336). X, Residue not clearly identified.

pattern on SDS gels clearly differed from that which was obtained with $\mathrm{MBP}_{\text {S.t. }}$.

CNBr-generated peptides were separated by HPLC, and the major peak fractions were subjected to sequence analysis. The sequences obtained from five such fragments are aligned best with the enterobacterial sequences as shown in Fig. 4. Strikingly, most amino acid replacements are found in fragments B1 (residues 99-111) (for which an alternative alignment, allowing gaps, is also given in Fig. 4) and B2 (residues 188-211), in which variations among the enterobacterial proteins are also clustered. Both peptide segments are dispensable for substrate binding, as recently demonstrated by solving the three-dimensional structure of $\mathrm{MBP}_{\boldsymbol{E} . c .}$ (Spurlino et al., 1991) as well as by linker insertion mutation (Duplay et al., 1987). However, the region between residues 207 and 220 in $\mathrm{MBP}_{E . c .}$, to which peptide fragments $\mathrm{B} 2$ and $\mathrm{B} 3$ of $\mathrm{MBP}_{A . h .}$ align, was suggested to be involved in the interaction of MBP with the membrane-integral components MalF and/or MalG of the transport complex (Duplay et al., 1987). This is in line with the observation described above that $\mathrm{MBP}_{A, h}$.

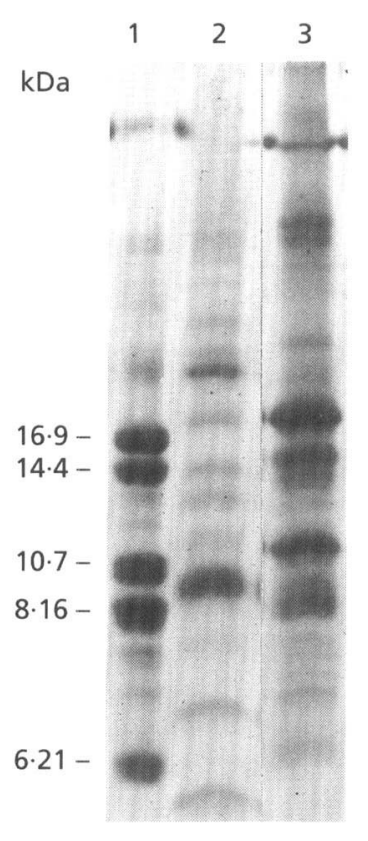

Fig. 5. Peptide fragments of $M B P_{A h}$ and $M B P_{S, t}$ generated by $\mathrm{CNBr}$ cleavage. Purified MBPs were cleaved by $\mathrm{CNBr}$ as described in Methods, subjected to SDS-PAGE (Schägger \& von Jagow, 1987), and peptides were stained with Coomassie blue. Lanes: 1, molecular mass standard (Merck); 2, $\operatorname{MBP}_{A . h .} ; 3$, $\mathrm{MBP}_{\text {S.t. }}$.

hardly restored transport activity of an E. coli strain deficient in the MBP (Fig. 3).

Together with the $\mathrm{N}$-terminal sequence of the native protein, the peptide fragments comprise about $20 \%$ of the complete primary structure, taking into account the apparent molecular mass of $39 \mathrm{kDa}$ on SDS gels. Given that the peptides are representative of the mature protein, the amino acid sequence of $\mathrm{MBP}_{A . h}$. exhibits about $56 \%$ identity to the E. coli MBPs.

\section{DISCUSSION}

A. bydrophila, a Gram-negative facultatively anaerobic bacterium, can grow on maltose and maltodextrins as the sole sources of carbon and energy. We have investigated the properties of maltose transport into this organism and the results presented in this communication can be summarized as follows: (i) the kinetic analysis of transport yielded $K_{\mathrm{m}}$ and $V_{\max }$ values that compare favourably with kinetic constants reported for enterobacterial maltosetransport systems (Dahl \& Manson, 1985); (ii) a binding protein with high affinity and high specificity was identified in the periplasm; (iii) partial sequence analysis and, to a lesser extent, reconstitution studies suggest that this protein is related to enterobacterial MBP. From this, we conclude that the uptake of maltose and maltodextrins in $A$. bydropbila is accomplished by a binding-proteindependent transport system. In line with this view is the recent identification of an outer-membrane protein in this organism, the level of which is increased in the presence of maltose in the medium (Jeanteur et al., 1992). Moreover, 
this protein was demonstrated to form a channel that was blocked by maltose. Both findings indicate that the protein might be functionally equivalent to the enterobacterial maltoporin (LamB). Together, these data provide the first evidence for a binding-protein-dependent transporter specific for maltose/maltodextrins in a Gram-negative non-enteric bacterium.

A. bydropbila and the Enterobacteriaceae belong to the same major evolutionary branch (Woese, 1987), exhibiting about $70 \%$ homology, based on rRNA/DNA hybridization experiments (Baumann \& Schubert, 1984). In addition, an $S_{a b}$ coefficient of 0.6 was determined from an analysis of $16 \mathrm{~S}$ rRNA (Ochman \& Wilson, 1987). Although only about $20 \%$ of the primary structure of $\mathrm{MBP}_{A . h}$. has been determined so far, the finding of $56 \%$ identical residues and about $75 \%$ similar residues when compared to the enterobacterial MBP matches nicely with these values. However, with respect to structural and functional aspects, our data also revealed that the differences between $\mathrm{MBP}_{A, h}$. and enterobacteria appear to be more pronounced. This is indicated by the very weak cross-reaction with anti-MBP ${ }_{S . h .}$ antiserum as well as by the poor performance of $\mathrm{MBP}_{A . h}$. in reconstitution experiments.

A special class of E. coli mutants with defects in the integral membrane components MalF and MalG, respectively, suggests that these proteins provide distinct binding sites for the substrate rather than forming a simple pore (Shuman, 1982; Dassa, 1993). However, the molecular nature of such a binding site is still unknown. The comparative analysis of sequences of analogous proteins from different organisms would provide one way to approach this problem. However, thus far, such studies are hampered by the limited number of suitable sequences available. While the enterobacterial proteins do not qualify for such an analysis due to their high sequence homology (>90\%) with each other (Dahl et al., 1989; Schneider et al., 1992), sequences from distantly related Gram-positive organisms, such as $C$. thermosulfurogenes (Bahl et al., 1991), Strep. mutans (Russell et al., 1992) and Strep. pneumoniae (Puyet \& Espinosa, 1993) display only about $25 \%$ identity with the enterobacterial proteins. Moreover, the substrate specificities of these transporters are different or unclear. Therefore, sequence data on the membrane-integral proteins of an organism like $A$. bydrophila, once available from the cloned genes, might turn out to be well suited for proposing putative maltose/maltodextrin-binding sites, thereby paving the way for the design of appropriate experiments. The purified MBP and a respective polyclonal antiserum (available shortly) will be useful tools in the course of cloning and sequencing the transport genes of this organism.

\section{ACKNOWLEDGEMENTS}

The authors are grateful to Dr R. Holländer (Bremen) for providing a culture of $A$. bydropbila and to Professor W. Boos (Konstanz) for the gift of E. coli strain HS3018. We also wish to thank E. Uhlemann and S. Tebbe for expert technical assistance. This work was supported by the Deutsche Forschungsgemein- schaft grants SFB $171 / \mathrm{C} 12$ and B4, and by the Fonds der Chemischen Industrie.

\section{REFERENCES}

Ames, G. F.-L. (1986). Bacterial periplasmic transport systems: structure, mechanism, and evolution, Annu Rev Biochem 55, 397-425.

Ames, G. F.-L., Mimura, C. S. \& Shyamala, V. (1990). Bacterial periplasmic permeases belong to a family of transport proteins operating from Escherichia coli to human: traffic ATPases. FEMS Microbiol Rev 75, 429-446.

Bahl, H., Burchhardt, G. \& Wienecke, A. (1991). Nucleotide sequence of two Clostridium thermosulfurogenes EM1 genes homologous to Escherichia coli genes encoding integral membrane components of binding protein-dependent transport systems. FEMS Microbiol Lett 81, 83-88.

Baumann, P. \& Schubert, R. H. W. (1984). Vibrionaceae. In Bergey's Manual of Systematic Bacteriology, vol. 1, pp. 516-517. Edited by N. R. Krieg \& J. G. Holt. Baltimore \& London: Williams \& Wilkins.

Brass, J. (1986). Calcium-induced permeabilization of the outer membrane: a method for reconstitution of periplasmic binding protein-dependent transport systems in Eschericbia coli and Salmonella typhimurium. Methods Enøymol 125, 289-302.

Brzostek, K., Heleszko, H. \& Hrebenda, J. (1993). Maltoporins and maltose-binding proteins of Yersinia enterocolitica. $J$ Gen Microbiol 139, 195-201.

Chakraborty, T., Montenegro, M. A., Sanyal, S. C., Helmuth, R., Bulling, E. \& Timmis, K. N. (1984). Cloning of enterotoxin gene from Aeromonas bydrophila provides exclusive evidence of production of a cytotoxic enterotoxin. Infect Immun 46, 435-441.

Chakraborty, T., Huhle, B., Hof, H., Bergbauer, H. \& Goebel, W. (1987). Marker exchange mutagenesis of the aerolysin determinant in Aeromonas bydropbila demonstrates the role of aerolysin in $A$. bydropbila-associated systemic infections. Infect Immun 55, 2274-2280.

Dahl, M. K. \& Manson, M. D. (1985). Interspecific reconstitution of maltose transport and chemotaxis in Escherichia coli with maltosebinding protein from various enteric bacteria. $J$ Bacteriol 164 , 1057-1063.

Dahl, M. K., Francoz, E., Saurin, W., Boos, W., Manson, M. D. \& Hofnung, M. (1989). Comparison of sequences from the malB regions of Salmonella typhimurium and Enterobacter aerogenes with Escherichia coli K12: a potential new regulatory site in the interoperonic region. Mol \& Gen Genet 218, 199-207.

Dassa, E. (1993). Sequence-function relationships in $M a l G$, an inner membrane protein from the maltose transport system in Escherichia coli. Mol Microbiol 7, 39-47.

Davidson, A. L. \& Nikaido, H. (1991). Purification and characterization of the membrane-associated components of the maltose transport system from Escherichia coli. J Biol Chem 266, 8946-8951.

Davidson, A. L., Shuman, H. A. \& Nikaido, H. (1992). Mechanism of maltose transport in Escherichia coli: transmembrane signaling by periplasmic binding proteins. Proc Natl Acad Sci USA 89, 2360-2364.

Dean, D. A., Hor, L. I., Shuman, H. A. \& Nikaido, H. (1992). Interaction between maltose-binding protein and the membraneassociated maltose transporter complex in Escherichia coli. Mol Microbiol 6, 2033-2040.

Dulley, J. R. \& Grieve, P. A. (1975). A simple technique for eliminating interference by detergents in the Lowry method of protein determination. Anal Biocbem 64, 136-141. 
Duplay, P., Szmelcman, S., Bedouelle, H. \& Hofnung, M. (1987). Silent and functional changes in the periplasmic maltose-binding protein of Escherichia coli K12. I. Transport of maltose. J Mol Biol 194, 663-673.

Ferenci, T. \& Klotz, U. (1978). Affinity chromatographic isolation of the periplasmic maltose binding protein of Escherichia coli. FEBS Lett 94, 213-217.

Gilson, E., Alloing, G., Schmidt, T., Claverys, J.-P., Dudler, R. \& Hofnung, M. (1988). Evidence for high affinity binding-protein dependent transport systems in Gram-positive bacteria and in Mycoplasma. EMBO 7, 3971-3974.

Gobius, K. I. \& Pemberton, J. M. (1988). Molecular cloning, characterization, and nucleotide sequence of an extracellular amylase gene from Aeromonas bydropbila. J Bacteriol 170, 1325-1332,

Higgins, C. F. (1992). ABC transporter: from microorganisms to man. Annu Rev Cell Biol 8, 67-113.

Janda, J. M. (1985). Biochemical and exoenzymatic properties of Aeromonas species. Diagn Microbiol Infect Dis 3, 223-232.

Jeanteur, D., Gletsu, N., Pattus, F. \& Buckley, J. T. (1992). Purification of Aeromonas bydrophila major outer-membrane proteins: $\mathrm{N}$-terminal sequence analysis and channel-forming properties. Mol Microbiol 6, 3355-3363.

Laemmli, U. K. (1970). Cleavage of structural proteins during the assembly of the head of bacteriophage T4. Nature 227, 680-685.

Leung, K. Y. \& Stevenson, R. M. W. (1988). Tn5-induced proteasedeficient strains of Aeromonas bydrophila with reduced virulence for fish. Infect Immun 56, 2639-2644.

Miller, J. H. (1972). Experiments in Molecular Genetics. Cold Spring Harbor, NY: Cold Spring Harbor Laboratory.

Nossal, N. G. \& Heppel, L. A. (1966). The release of enzymes by osmotic shock from Escherichia coli in exponential phase. $J$ Biol Chem 241, 3055-3062.

Ochman, H. \& Wilson, A. C. (1987). Evolutionary history of enteric bacteria. In Escherichia coli and Salmonella typhimurium. Cellular and Molecular Biology, pp. 1649-1654. Edited by J. L. Ingraham, K. B. Low, B. Magasanik \& H. E. Umbarger. Washington, DC: American Society for Microbiology.

Puyet, A. \& Espinosa, M. (1993). Structure of the maltodextrinuptake locus of Streptococcus pneumoniae. Correlation to the Escherichia coli maltose regulon. J Mol Biol 230, 800-811.

Roth, J. R. (1970). Genetic techniques in studies of bacterial metabolism. Methods Enzymol 17, 3--35.

Russell, R. R. B., Aduse-Opoku, J., Sutcliffe, I. C., Tao, L. \& Ferretti, J. J. (1992). A binding protein-dependent transport system in
Streptococcus mutans responsible for multiple sugar metabolism. I Biol Chem 267, 4631-4637.

Schăgger, H. \& von Jagow, G. (1987). Tricine-sodium dodecyl sulfate-polyacrylamide gel electrophoresis for the separation of proteins in the range from 1 to $100 \mathrm{kDa}$. Anal Biochem 166, 368-379.

Schneider, E. (1990). Periplasmic binding protein-dependent transport of maltose/maltodextrins in Escherichia coli and Salmonella typhimurium. In Trends in Biomembranes and Bioenergetics, vol. 1, pp. 201-218. Edited by A. Jacob. Trivandrum, India: Research Trends.

Schneider, E., Francoz, E. \& Dassa, E. (1992). Completion of the nucleotide sequence of the 'maltose B' region in Salmonella typhimurium: the high conservation of the malM gene suggests a selected physiological role for its product. Biochim Biophys Acta 1129, 223-227.

Schwartz, M. (1987). The maltose regulon. In Escherichia coli and Salmonella typhimurium. Cellular and Molecular Biology, pp. 1482-1502. Edited by J. L. Ingraham, K. B. Low, B. Magasanik \& H. E. Umbarger. Washington, DC: American Society for Microbiology.

Shuman, H. A. (1982). Active transport of maltose in Escherichia coli $\mathrm{K} 12$. Role of the periplasmic maltose-binding protein and evidence for a substrate recognition site in the cytoplasmic membrane. J Biol Chem 247, 5455-5461.

Spurlino, J. C., Lu, G.-Y. \& Quiocho, F. A. (1991). The $2.3-\AA$ resolution structure of the maltose- or maltodextrin-binding protein, a primary receptor of bacterial active transport and chemotaxis. J Biol Chem 266, 5202-5219.

Tagney, M., Buchanan, C. J., Priest, F. G. \& Mitchell, W. J. (1992a). Maltose uptake and its regulation in Bacillus subtilis. FEMS Microbiol Lett 97, 191-196.

Tagney, M., Smith, P., Priest, F. G. \& Mitchell, W. J. (1992b). Maltose transport in Bacillus licheniformis NCIB 6346.J Gen Microbiol 138, 1821-1827.

Walker, J. E., Saraste, M., Runswick, M. J. \& Gay, N. J. (1982). Distantly related sequences in the $\alpha$ - and $\beta$-subunits of ATP synthase, myosin, kinases and other ATP-requiring enzymes and a common nucleotide binding fold. EMBO J 1, 945-951.

Walter, C., Honer zu Bentrup, K. \& Schneider, E. (1992). Large scale purification, nucleotide binding properties, and ATPase activity of the MalK subunit of Salmonella typbimurium maltose transport complex. J Biol Chem 267, 8863-8869.

Woese, C. R. (1987). Bacterial evolution. Microbiol Rev 51, 221-271.

Received 9 August 1993; revised 5 October 1993; accepted 11 October 1993. 